\title{
Impact of Bio-accelerated Farming against Conventional Farming System on Green Gram (Vigna radiata L.) under Rainfed Condition: Adaptive Management Enhances the Resilience to Climate Change
}

\author{
Dipen Dahal ${ }^{1}$, J. Ghosh ${ }^{2}$ and Binoy Chhetri ${ }^{3 *}$
}

\author{
${ }^{1}$ Assistant Director of Agriculture, Madarihat Block, Alipurduar, West Bengal (736 122) India \\ ${ }^{2}$ Dept. of Agricutural Entomology, Faculty of Agriculture, UBKV, Pundibari, Coochbehar (736 165), India \\ ${ }^{3}$ Regional Research Station (HZ), Uttar Banga Krishi Viswavidyalaya, Kalimpong, West Bengal (734 301), India
}

\section{Corresponding Author}

Binoy Chhetri

e-mail: yonib2050@gmail.com

\author{
Article History \\ Article ID: AR1947 \\ Received in 09 ${ }^{\text {th }}$ January, 2019 \\ Received in revised form $23^{\text {rd }}$ February, 2019 \\ Accepted in final form 28 ${ }^{\text {th }}$ February, 2019
}

\begin{abstract}
The field experiments was conducted at the Instructional Farm of Uttar Banga Krishi Viswavidyalaya, Pundibari, Coochbehar, West Bengal, India during 2011-2012. The objective was to assess the effect of chemical free bio-accelerated and conventional farming system on growth, yield attributes, yield, nutrients uptake, quality and microbial population of green gram. The farm is situated at $26^{\circ} 19^{\prime} 86^{\prime \prime} \mathrm{N}$ latitude and $89^{\circ} 23^{\prime} 53^{\prime \prime}$ E longitude at an elevation of $43.0 \mathrm{~m}$ above mean sea level. Results revealed that the growths, yield attributes, quality and microbial population of green gram were recorded higher in chemical free bio-accelerated compared to the conventional farming system. From the pooled data the highest yield was recorded under bio-accelerated farming $\left(1500 \mathrm{~kg} \mathrm{ha}^{-1}\right)$ compared to the conventional farming system $\left(1375 \mathrm{~kg} \mathrm{ha}^{-1}\right)$. The highest moisture percentage recorded under conventional farming (65.37\%) than bio-accelerated farming system (63.35\%). The nitrogen (50.40 and $\left.73.88 \mathrm{~kg} \mathrm{ha}^{-1}\right)$, phosphorus (10.53 and $11.32 \mathrm{~kg} \mathrm{ha}^{-1}$ ) and potassium (67.68 and $\left.123.60 \mathrm{~kg} \mathrm{ha} \mathrm{a}^{-1}\right)$ uptake by crop was recorded highest under the conventional farming compared to bio-accelerated farming system. The application jiwanmrita recorded significantly higher number of microbial population in the soil of bio-accelerated farming than the conventional farming system. From the pooled data analysis showed 62.50 microbes in bio-accelerated and 39.75 microbes in conventional farming before sowing which increased up to 97.25 microbes and decreased to 31.94 microbes in bio-accelerated and Conventional farming system. Among the chemical free bio-accelerated farming system pest incidence was found to be lower as compared to the conventional farming system.
\end{abstract}

Keywords: Bio-accelerated, conventional, greengram, growth, nutrient uptake

\section{Introduction}

Greengram or mungbean (Vigna radiata L.) is a third most important pulse crop of India after chickpea and pigeon pea (Tamang et al., 2015). However, major greengram producing states are Odissa, Madhya Pradesh, Rajasthan, Maharashtra, Gujarat and Bihar. It is cultivated over an area of 3.04 mha with a total production of $1.42 \mathrm{mt}$ and productivity of 468 $\mathrm{kg} \mathrm{ha}^{-1}$ (Anon, 2016). Green gram is an excellent source of protein $(24.5 \%)$ with high quality of lysine $\left(460 \mathrm{mg} \mathrm{g}^{-1} \mathrm{~N}\right.$ ) and tryptophan $\left(60 \mathrm{mg} \mathrm{g}^{-1} \mathrm{~N}\right)$ and rich in protein and vitamin B. It contains also remarkable quantity of ascorbic acid and riboflavin (0.21 mg $100 \mathrm{~g}^{-1}$ ) (Azadi et al. 2013). However, the yield of pulse crops is low due to lack of awareness in adoption of improved technology (Kumar, 2014b). The dose of fertilizer depends on the initial status soil fertility and soil moisture availability conditions (Saravanan et al.,
2013). Moreover, greengram required more macro nutrients compared to the other pulse crops. In these cases farmers are applying large quantities of inorganic fertilizers without understanding its negative impact in the fertility status of the soil as well as the concerned environment (Baishya, 2015). Instead, restoring soil health by re-adopting chemical free agriculture would be a path towards sustainability (Tripura et al., 2016). In this regards, low yields of green gram are largely associated with uncertain rainfall, poor soil fertility, high weeds, pests, diseases infestation, low input availability, low input use and unavailability of appropriate variety and seeds (Singh and Sekhon, 2008). Hence, the climate variability is a major challenge to the crop production in this region. In this context adaption of chemical free bio-accelerated farming system does have the potential to produce enough food to feed the World. Developed of new technology like indigenous microbial culture prepared by mixing cow- 
dung, cow-urine, mixed with pulse powder and molasses for their energy sources without any investment of costlier inputs from external sources. Use of organic mulch from crop residues continuously supply humus to improve soil quality and fertility through accelerating dynamics biological processes like enhancing activities of microorganisms, earth worms, parasites, predators and induced resistance against pest and disease which ultimately lead into sustained supply of plant nutrients and keep the pest and disease incidence always at lower level leading to betterment of the crop yield (Palekar, 2001). Moreover, adaptive management of natural resources enhances resilience to climate variability. Therefore, there is a direct need to systematically redirect agricultural knowledge, science and technology towards sustainable, biodiversity-based ecological agriculture and the underlying agro-ecological science. This is because it is postulated that the ecological model of agricultural production, which is based on principles that prioritize farmers and traditional knowledge, is climate resilient as well as productive. On the other hand, indigenously prepared microbial culture like jiwamrita and organic mulches are the major sources of nutrients in bioaccelerated farming. The practices recently are gaining much popularity to enhance and maintain soil organic status for obtaining a sustainable crop yield (Ravi et al., 2012).

So, in this context the approach for chemical free bioaccelerated farming provides a better solution for conjunctive use of natural resources (organic) of plant nutrients for crop productivity as well as sustaining soil health and environment. Considering the above mentioned reason a study on growth, yield and quality of greengram as influence by chemical free bio-accelerated farming system.

\section{Materials and Methods}

The field experiment was carried out at Instructional Farm of Uttar Banga Krishi Viswavidyalaya, Pundibari, Coochbehar, West Bengal, India during 2013 and 2014. The farm is situated at $26^{\circ} 19^{\prime} 86^{\prime \prime} \mathrm{N}$ latitude and $89^{\circ} 23^{\prime} 53^{\prime \prime} \mathrm{E}$ longitude at an elevation of $43.0 \mathrm{~m}$ above mean sea level. The soil of the experimental field was sandy loam in texture with $\mathrm{pH}$ 5.7. The experimental area was divided by two types (treatments) of farming system viz. bio-accelerated and conventional farming. For bio-accelerated farming system indigenous microbial culture (Jiwamrita) was prepared with fresh cow dung, cow urine, lime and a handful of soil from the bund (uncultivated soil). After sowing, the indigenous microbial culture (Jiwamrita) prepared by fresh cow dung $(10 \mathrm{~kg})+$ cow urine (10 litre)+molasses (2 kg)+pulse dust $(2 \mathrm{~kg})+$ handful of bund soil mixed in water (200 liter for one acre) stirred thrice daily for three days was applied at 15 days interval till grain filling stage. Application was done by spreading diluted microbial culture according to its requirement entirely in the plots at late afternoon hours simply with plastic mug available. The results were analyzed taking consideration of pre harvest parameters like plant height $(\mathrm{cm})$, root length $(\mathrm{cm})$, leaf width (cm), number of nodule plant ${ }^{-1}$, nodule weight plant ${ }^{-1}$, trichem plant $^{-1}$ and number of branches plant ${ }^{-1}$ at 30, 60, 90 days after sowing (DAS) and at harvest where as post harvest parameters were number of pod plant ${ }^{-1}$, pod length $(\mathrm{cm})$, pod weight (g), number of seeds pod ${ }^{-1}, 100$-seed weight (g), grain length $(\mathrm{cm})$ and grain yield $\left(\mathrm{kg} \mathrm{ha}^{-1}\right)$. Estimation of micro-organism population was done by the methods of Waksman and Fred (1922) after the samples were homogenized in mortar with a pestle and sieve through 2-mm sieve. One gram each of organic based and inorganic based soil sample were mixed with $9 \mathrm{ml}$ of sterile distilled water in two different test tube to prepare $10^{-1}$ dilution. These suspensions were used for serial dilution up to $10^{-7}$. One $\mathrm{ml}$ of each suspension from $10^{-5}$ to $10^{-7}$ were plated separately in potato dextrose agar medium and incubated at $28 \pm 1{ }^{\circ} \mathrm{C}$ for $3-5$ days. The moisture percentage was determined by following the procedure of Paul et al. (1992).

Moisture \%=(Weight of fresh leaves-Weight of dry leaves $) /$ Weight of fresh leaves $\times 100$

Economic analyses were gross return, net return and benefit cost ratio. The replicated data generated were analyzed statistically using statistical package of SAS and determined the probability for significant variation among the treatments.

\section{Results and Discussion}

\subsection{Relative performance of vegetative parameters of green gram}

Plant height of green gram highest was recorded under bioaccelerated farming compared to the conventional farming system at all stages of crop growth. The height of plant increased with the advancement of the crop age due to its growth and reached its maximum at harvest irrespective of the treatments tried. However, it was revealed that from the pooled data the height of the plant was increased gradually from $22.54 \mathrm{~cm}$ and $23.91 \mathrm{~cm}$ at 30 DAS; $51.96 \mathrm{~cm}$ and 51.41 $\mathrm{cm}$ at 60 DAS and $58.62 \mathrm{~cm}$ and $57.11 \mathrm{~cm}$ at maturity in conventional farming and bio-accelerated farming system (Table 1). The maximum plant height in bio-accelerated farming system might be due to stimulated biological activities which enhanced the plant growth by improving soil nutrient status, secreting plant growth regulators and suppressing insect pest populations throughout growth period. The application of organic source of nutrients such as farm yard manure and vermicompost significantly enhance the plant height of green gram (Singh and Singh, 2014). From the ' $t$ '-test value it was revealed that plant height was non-significant in all observations of 30 DAS, 60 DAS and at maturity (Table 2). The highest number of branches plant ${ }^{-1}$ was recorded at 30 days after sowing in bio-accelerated (4.02) and conventional farming (4.27) branches plant ${ }^{-1}$. The highest number of branch plant ${ }^{-1}$ at maturity was recorded under bio-accelerated ( 8.12 branches plant $^{-1}$ ) compared to the conventional farming system (7.48 branches plant ${ }^{-1}$ ) (Table 


\begin{tabular}{|c|c|c|c|c|c|c|c|}
\hline \multirow[t]{2}{*}{ Plant parameters } & \multirow{2}{*}{$\begin{array}{c}\text { Stage of } \\
\text { observation }\end{array}$} & \multicolumn{2}{|c|}{$1^{\text {st }}$ year } & \multicolumn{2}{|c|}{$2^{\text {nd }}$ year } & \multicolumn{2}{|c|}{ Pooled } \\
\hline & & $\mathrm{BF}$ & $\mathrm{CF}$ & $\mathrm{BF}$ & $\mathrm{CF}$ & $\mathrm{BF}$ & $\mathrm{CF}$ \\
\hline \multirow[t]{3}{*}{ Plant height (cm) } & 30DAS & 24.12 & 25.08 & 20.96 & 22.74 & 22.54 & 23.91 \\
\hline & 60DAS & 50.00 & 49.34 & 53.91 & 53.49 & 51.96 & 51.41 \\
\hline & At maturity & 56.45 & 55.31 & 60.80 & 58.92 & 58.62 & 57.11 \\
\hline \multirow[t]{3}{*}{ Root length (cm) } & 30DAS & 13.19 & 14.22 & 11.54 & 11.41 & 12.36 & 12.81 \\
\hline & 60DAS & 15.44 & 15.41 & 14.46 & 16.02 & 14.95 & 15.72 \\
\hline & At maturity & 21.04 & 20.27 & 24.37 & 26.20 & 22.70 & 23.23 \\
\hline \multirow[t]{3}{*}{ Nodules plant ${ }^{-1}$} & 30DAS & 28.33 & 21.00 & 26.67 & 23.12 & 27.50 & 22.06 \\
\hline & 6ODAS & 34.33 & 22.67 & 30.67 & 24.42 & 32.50 & 23.54 \\
\hline & At maturity & 31.42 & 20.88 & 22.67 & 20.63 & 27.04 & 20.75 \\
\hline \multirow[t]{3}{*}{ Nodules wt. plant ${ }^{-1}$} & 30DAS & 1.71 & 0.97 & 2.21 & 2.00 & 1.96 & 1.49 \\
\hline & 6ODAS & 2.14 & 1.29 & 2.44 & 2.06 & 2.29 & 1.68 \\
\hline & At maturity & 2.41 & 1.44 & 2.27 & 2.05 & 2.34 & 1.74 \\
\hline \multirow[t]{3}{*}{ Leaf width $(\mathrm{cm})$} & 30DAS & 6.35 & 6.41 & 6.24 & 5.75 & 6.30 & 6.08 \\
\hline & 60DAS & 8.25 & 8.24 & 7.31 & 7.32 & 7.78 & 7.78 \\
\hline & At maturity & 8.29 & 8.23 & 7.60 & 7.86 & 7.94 & 8.05 \\
\hline \multirow[t]{3}{*}{ Trichme leaf ${ }^{-1}$} & 30DAS & 9.13 & 5.67 & 5.80 & 4.63 & 7.46 & 5.15 \\
\hline & 60DAS & 14.96 & 10.13 & 9.33 & 5.33 & 12.15 & 7.73 \\
\hline & At maturity & 13.83 & 9.92 & 11.79 & 7.75 & 12.81 & 8.83 \\
\hline \multirow[t]{3}{*}{ Branches plant $^{-1}$} & 30DAS & 4.00 & 3.79 & 4.04 & 4.75 & 4.02 & 4.27 \\
\hline & 60DAS & 5.00 & 4.88 & 6.00 & 7.13 & 5.50 & 6.00 \\
\hline & At maturity & 8.00 & 7.54 & 8.25 & 7.42 & 8.12 & 7.48 \\
\hline Moisture percentage (\%) & At maturity & 61.48 & 64.19 & 65.22 & 66.55 & 63.35 & 65.37 \\
\hline Pods plant $^{-1}$ & At maturity & 27.58 & 26.17 & 31.67 & 29.46 & 29.63 & 27.81 \\
\hline Pod length $(\mathrm{cm})$ & At maturity & 11.01 & 10.75 & 9.67 & 9.45 & 10.34 & 10.10 \\
\hline Pod wt. (g) & At maturity & 0.61 & 0.59 & 0.51 & 0.50 & 0.56 & 0.55 \\
\hline Grains pod ${ }^{-1}$ & At maturity & 13.33 & 12.92 & 12.42 & 11.75 & 12.88 & 12.33 \\
\hline 100 grain wt. (g) & At maturity & 4.87 & 4.72 & 4.68 & 4.48 & 4.77 & 4.60 \\
\hline Grain length $(\mathrm{cm})$ & At maturity & 0.46 & 0.42 & 0.40 & 0.36 & 0.43 & 0.39 \\
\hline Yield $\left(\mathrm{kg} \mathrm{ha}^{-1}\right)$ & At maturity & 1521.30 & 1367.40 & 1479.80 & 1382.60 & 1500.50 & 1375.00 \\
\hline
\end{tabular}

BF: Bio-accelerated; CF: Conventional farming

1). This might be due to the application of organic sources nutrients like jiwamitra are the store house of plant nutrients which might have improved the physico-chemical as well as biological properties of the soil to enhance the number of branches plant ${ }^{-1}$ (Table 1 ). These results also conformity with the findings of Giri and Joshi (2010) and Sinha et al. (2010). The ' $t$ '-test revealed that number of branches plant ${ }^{-1}$ was nonsignificant between two practices (Table 2). However, the root length of the plant was observed from 30 days after sowing upto maturity stage. The length of root at $30 \mathrm{DAS}$ is (12.36 and $12.81 \mathrm{~cm})$, at 60 DAS (14.95 and $15.72 \mathrm{~cm}$ ) and at maturity
$(22.70$ and $23.23 \mathrm{~cm})$ in bio-accelerated and conventional farming system (Table 1). The increased of root length on chemical free bio accelerated farming system might be due to application nutrients like jiwamitra under this fertility levels favoured the root proliferation by stimulating cellular activities and translocation of certain growth stimulating compounds to roots. However, Sutaria et al. (2010) reported that the extensive root growth and development system with balanced fertilization and organic manure assisted the efficient absorption and utilization of other nutrients. The values of ${ }^{\prime} \mathrm{t}$ test showed that the root length showed non-significant 


\begin{tabular}{|c|c|c|c|}
\hline Plant parameters & $\begin{array}{c}\text { Stage of } \\
\text { observation }\end{array}$ & $\begin{array}{c}\mathrm{t}- \\
\text { value }\end{array}$ & $\operatorname{Pr}>t$ \\
\hline \multirow[t]{3}{*}{ Plant height (cm) } & 30 DAS & -1.95 & 0.0611 \\
\hline & 60 DAS & 0.52 & 0.6076 \\
\hline & At Maturity & 1.31 & 0.1999 \\
\hline \multirow[t]{3}{*}{ Root length (cm) } & 30 DAS & -0.86 & 0.3979 \\
\hline & 60 DAS & -3.09 & 0.0043 \\
\hline & At Maturity & 0.45 & 0.6590 \\
\hline \multirow[t]{3}{*}{ Nodules plant ${ }^{-1}$} & 30 DAS & 5.54 & $<.0001$ \\
\hline & 60 DAS & 8.99 & $<.0001$ \\
\hline & At Maturity & 4.00 & 0.0004 \\
\hline \multirow[t]{3}{*}{ Nodules wt. plant ${ }^{-1}$} & 30 DAS & 2.21 & 0.0345 \\
\hline & 60 DAS & 4.19 & 0.0002 \\
\hline & At Maturity & 5.52 & $<.0001$ \\
\hline \multirow[t]{3}{*}{ Leaf width $(\mathrm{cm})$} & 30 DAS & 1.96 & 0.0596 \\
\hline & 60 DAS & 0.00 & 1.0000 \\
\hline & At Maturity & -0.91 & 0.3712 \\
\hline \multirow[t]{3}{*}{ Trichme leaf $^{-1}$} & 30 DAS & 4.12 & 0.0003 \\
\hline & 60 DAS & 3.35 & 0.0022 \\
\hline & At Maturity & 4.92 & $<.0001$ \\
\hline \multirow[t]{3}{*}{ Branches plant $^{-1}$} & 30 DAS & -0.73 & 0.4711 \\
\hline & 60 DAS & -1.28 & 0.2101 \\
\hline & At maturity & 1.73 & 0.0944 \\
\hline Moisture percentage (\%) & At maturity & -2.65 & 0.0128 \\
\hline Pods plant $^{-1}$ & At maturity & 1.27 & 0.2145 \\
\hline Pod length (cm) & At maturity & 0.89 & 0.3831 \\
\hline Pod wt. (g) & At maturity & 0.58 & 0.5635 \\
\hline Grains pod $^{-1}$ & At maturity & 1.55 & 0.1321 \\
\hline 100 grain wt. (g) & At maturity & 2.22 & 0.0343 \\
\hline Grain length $(\mathrm{cm})$ & At maturity & 2.41 & 0.221 \\
\hline Yield $\left(\mathrm{kg} \mathrm{ha}^{-1}\right)$ & At maturity & 7.76 & $<.0001$ \\
\hline
\end{tabular}

DAS: Days after sowing

relation between the treatments (except 60 DAS where root length was significantly higher in conventional farming) at all stages of growth (Table 2).

From the data it was revealed that the bio-accelerated farming system produced maximum number of nodules plant ${ }^{-1}$ compared to the conventional farming practices. The average number of nodules plant ${ }^{-1}$ at 30 DAS was $^{27.50}$ nodules plant ${ }^{-1}$ and 22.06 nodules plant $^{-1}, 32.50$ nodules plant ${ }^{-1}$ and on 23.54 nodules plant ${ }^{-1}$ at 60 DAS and at maturity it was 27.04 nodules plant ${ }^{-1}$ and 20.75 nodules plant $^{-1}$ in bio-accelerated and conventional farming system (Table 1 ). Weight of the nodules plant ${ }^{-1}$ was significantly higher in bio-accelerated farming compared to the Conventional farming system. From the pooled data the average weight of the nodules plant ${ }^{-1}$ was 1.96 g plant $^{-1}$ at 30 DAS in bio-accelerated farming 1.49 g plant $^{-1}$ in conventional farming, during 60 DAS it was 2.29 $\mathrm{g} \mathrm{plant}^{-1}$ in bio-accelerated farming and $1.68 \mathrm{~g} \mathrm{plant}^{-1}$ in conventional farming while at maturity, it was $2.34 \mathrm{~g} \mathrm{plant}^{-1}$ in bio-accelerated and $1.74 \mathrm{~g} \mathrm{plant}^{-1}$ in Conventional farming system (Table 1 ). Maximum number of nodule plant ${ }^{-1}$ and nodules weight in bio-accelerated might be due to availability of macro and micronutrients from applied organic nutrients which improving the micro environment of root growth and number of nodules plant ${ }^{-1}$ Singh et al. (2011). Hence ' $t$ '-test revealed that, the number of nodules plant ${ }^{-1}$ and weight of nodules plant ${ }^{-1}$ was significantly higher in bio-accelerated farming compared to the conventional farming system (Table 2).

The highest leaf width was recorded $6.30 \mathrm{~cm}$ in bioaccelerated farming and $6.08 \mathrm{~cm}$ in conventional farming at 30 DAS. However, from the pooled data it was revealed that at 60 DAS the leaf width was found to be at par in the both farming system. At maturity the size of the leaf was maximum $(8.05$ and $7.94 \mathrm{~cm})$ under the conventional farming than bioaccelerated (Table 1). This might be due to the absorption and translocation of applied synthetic nutrients is easily available during active vegetative growth of plant in conventional farming system. From the ' $t$ '-test it was revealed that the leaf width on bio-accelerated farming and conventional farming was non-significant. The trichome leaf ${ }^{-1}$ was 7.46 and 5.15 trichome leaf $^{-1}$ at 30 DAS, 12.15 and 7.73 trichome leaf $^{-1}$ at 60 DAS and at maturity it was 12.81 trichome leaf $^{-1}$ and 8.83 trichome leaf $^{-1}$ in bio-accelerated and chemical farming (Table 1). ' $t$ '-test showed that trichome leaf ${ }^{-1}$ had significant relation between the treatments at all stages of growth i.e. bio-accelerated farming recorded more trichome leaf ${ }^{-1}$ than conventional farming (Table 2). Moisture percentage was always found to be higher in bio-accelerated farming (65.37\%) compared to the conventional farming (63.35\%) (Table 1). ' $t$ '-test showed, significant higher percentage of moisture in conventional than bio-accelerated farming (Table 2).

\subsection{Relative performance of yield attributing and yield}

Irrespective of bio-accelerated and conventional farming system yield attributes such as number of pods plant ${ }^{-1}$, pod length, grain length, seeds pod $^{-1}$, pod weight, test weight and yield as more in bio-accelerated farming system due to more vigorous growth of the crop which was reflected on yield attributes of greengram. However, from the pooled data it was pertinent that the highest number of pods plant ${ }^{-1}$ was recorded in bio-accelerated (29.63) and conventional farming (27.81) (Table 1). The length of pod was $10.34 \mathrm{~cm}$ in bio-accelerated and $10.10 \mathrm{~cm}$ in conventional farming. The highest grain length of $0.43 \mathrm{~cm}$ was recorded in bioaccelerated compared to the $0.39 \mathrm{~cm}$ in conventional farming. 
Bio-accelerated farming (12.88) was recorded highest number of seeds pod $^{-1}$ than conventional farming system (12.33). From the pooled data it was revealed that the pod weight maximum recorded under ( 0.56 and $\left.0.55 \mathrm{~g} \mathrm{pod}^{-1}\right)$ in bioaccelerated farming and conventional farming (Table 1 ). This might be due to the increased population of microbes which helps mobilization of the nutrients from unavailable form to available form. The similar result also made by Rajkhowa et al. (2002) in greengram the application of organic source of nutrients significantly increases the number of seed pod $^{-1}$. From the ' $\mathrm{t}^{\prime}$-test analysis showed the number of pods plant ${ }^{-1}$, length of pod, numbers of seeds pod ${ }^{-1}$, grain length and pods weight were significantly higher in bio-accelerated farming than the conventional farming though the values were nonsignificant between the treatments (Table 2). From the pooled data highest test weight was recorded under bio-accelerated farming ( $4.77 \mathrm{~g}$ ) compared to the conventional farming system (4.60 g) (Table 1). The application of organic sources nutrient like Jiwamitra and other organic source of nutrients are the store house of plant nutrients which might have improved the physico-chemical as well as biological properties of the soil to enhance yield attributes. However, application of only chemical fertilizers for the soils which deprived all the these advantages necessary for more production of functioning leaves, greater accumulation of carbohydrates, protein and their translocation to the reproductive organs, which in turn increased the number of pods plant ${ }^{-1}$, number of seeds pods ${ }^{-1}$ and other associated yield attributing parameters (Table 1).
These results are in conformity with the findings of Kumar et al. (2010), Dekhane et al. (2011) and Sharma and Verma (2011). From ' $t$ '-test revealed that seed index/100 seed weight was found to be significant between the two treatments i.e. bio-accelerated farming and conventional farming (Table 2). The highest yield was recorded under bio-accelerated farming (1500.5 kg ha-1) compared to the in conventional farming systems (1375.0 kg ha-1) (Table 1 ). This might be due to the fact that soils of bio-accelerated farming system contained enough indigenous microbial population to allow maximum growth and yield. These results are in conformity with the finding of Kumar and Kumar (2006). The' $t$ 't-test comparison showed that the yield showed significant difference between bio-accelerated farming and conventional farming (Table 2).

\subsection{Effect of treatments on availability and uptake of nutrients}

\subsubsection{Nutrients status}

Nutrient status of the soil was analyzed and found that the availability of nitrogen was lower in bio-accelerated farming system as compare to the conventional farming system. The highest availability of nitrogen was recorded under conventional farming system ( $\left.123.97 \mathrm{~kg} \mathrm{ha}^{-1}\right)$ compare to the bio-accelerated farming system (121.24 kg ha-1) (Table 3$)$. This might be owing to the continuous application of inorganic fertilizers on conventional farming system enhanced the nitrogen availability in soil. However, Ginting et al., (2003) reported that the continuous application of organic manures increases the level of N, P and K, in the soil. The application

Table 3: Nutrient status in the soil and nutrient uptake by green gram

\begin{tabular}{|c|c|c|c|c|c|c|}
\hline \multirow[t]{2}{*}{ Nutrients } & \multicolumn{2}{|c|}{$1^{\text {st }}$ year } & \multicolumn{2}{|c|}{$2^{\text {nd }}$ year } & \multicolumn{2}{|c|}{ Pooled } \\
\hline & BF & $\mathrm{CF}$ & BF & $\mathrm{CF}$ & $\mathrm{BF}$ & CF \\
\hline Available Nitrogen $\left(\mathrm{kg} \mathrm{ha}^{-1}\right)$ & 118.86 & 119.62 & 123.62 & 128.32 & 121.24 & 123.97 \\
\hline Nitrogen uptake $\left(\mathrm{kg} \mathrm{ha}^{-1}\right)$ & 49.20 & 70.96 & 51.60 & 76.81 & 50.40 & 73.88 \\
\hline Available Phosphorous (kg ha-1) & 17.35 & 17.75 & 18.11 & 19.84 & 17.73 & 18.79 \\
\hline Phosphorous uptake $\left(\mathrm{kg} \mathrm{ha}^{-1}\right)$ & 9.66 & 10.53 & 11.41 & 12.11 & 10.53 & 11.32 \\
\hline Available Potassium (kg ha-1) & 64.50 & 65.73 & 64.60 & 68.60 & 64.55 & 67.16 \\
\hline Potassium uptake ((kg ha-1) & 67.82 & 123.04 & 67.55 & 124.16 & 67.68 & 123.60 \\
\hline \multicolumn{7}{|c|}{ BF: Bio-accelerated farming; CF: Conventional farming } \\
\hline
\end{tabular}

of FYM, vermicompost and green leaf manures in releasing $\mathrm{N}$ and improving $\mathrm{N}$ availability in soil (Singh et al., 2008). Hence, ' $\mathrm{t}$ '- test of statistical analysis revealed that nitrogen availability showed similar trend between the bio-accelerated and conventional farming system and was found to be nonsignificant (Table 4). From the pooled data suggested that conventional farming recorded higher available phosphorous (18.79 $\mathrm{kg} \mathrm{ha}^{-1}$ ) than bio-accelerated farming (17.73 $\left.\mathrm{kg} \mathrm{ha}^{-1}\right)$. The status of the soil after harvest was also improved and enhances the fertility of soil this might be due to residual effect of organic nutrients. Similar findings also reported by Tanwar et al. (2010) and Patel (2012). This might be due to the

\begin{tabular}{|c|c|c|c|c|c|c|}
\hline Nutrients & $\begin{array}{l}\text { Available nitro- } \\
\text { gen }\left(\mathrm{kg} \mathrm{ha}^{-1}\right)\end{array}$ & $\begin{array}{c}\text { Nitrogen } \\
\text { Uptake }\left(\mathrm{kg} \mathrm{ha}^{-1}\right)\end{array}$ & $\begin{array}{l}\text { Available phos- } \\
\text { phorous }\left(\mathrm{kg} \mathrm{ha}^{-1}\right)\end{array}$ & $\begin{array}{c}\text { Phosphorous } \\
\text { uptake }\left(\mathrm{kg} \mathrm{ha}^{-1}\right)\end{array}$ & $\begin{array}{l}\text { Available potas- } \\
\text { sium }\left(\mathrm{kg} \mathrm{ha}^{-1}\right)\end{array}$ & $\begin{array}{l}\text { Potassium up- } \\
\text { take }\left(\mathrm{kg} \mathrm{ha}^{-1}\right)\end{array}$ \\
\hline t-value & -1.68 & -17.75 & -1.76 & -1.69 & -1.93 & -57.28 \\
\hline $\operatorname{Pr}>t$ & 0.1042 & $<.0001$ & 0.0893 & 0.1005 & 0.0636 & $<.0001$ \\
\hline
\end{tabular}


addition of organic manure or their different combinations, favored the availability of higher phosphorus in soil (Table 3 ). The results were compared on' $t$ '- test analyzing method and it showed that available phosphorous in bio-accelerated farming was non-significant to conventional farming system (Table 4). Available potassium in the soil was also less in the bio-accelerated farming than conventional farming. Pooled data showed that available potassium of $64.55 \mathrm{~kg} \mathrm{ha}^{-1}$ in bioaccelerated and $67.16 \mathrm{~kg} \mathrm{ha}^{-1}$ in conventional farming system were recorded (Table 3). Hence, it is confirmed that availability of potassium was non-significant between the treatments after analyzing on' $\mathrm{t}$ '-test statistical analysis i.e. potassium was higher in conventional farming than bio-accelerated farming (Table 4).

\subsubsection{Nutrient uptake}

Nutrient uptake by the greengram crop was always higher in the conventional farming than bio-accelerated farming which was measured at maturity. The pooled data, nitrogen uptake $50.40 \mathrm{~kg} \mathrm{ha}^{-1}$ was recorded in bio-accelerated farming while $73.88 \mathrm{~kg} \mathrm{ha}^{-1}$ in conventional farming system (Table $3)$. Hence, 't'-test showed significant variation between the treatments or conventional farming plants showed significantly better uptake of nitrogen than plants of bioaccelerated farming system (Table 4). Uptake of phosphorous was also similar to nitrogen as conventional was higher than bio-accelerated farming. From the pooled data, the uptake of phosphorous was $10.53 \mathrm{~kg} \mathrm{ha}^{-1}$ in bio-accelerated farming and (11.32 kg ha-1) uptake of phosphorous in conventional farming (Table 3 ). The results showed that uptake of phosphorous were significantly higher in conventional farming than bio-accelerated farming. ' $t$ '-test suggested that, uptake of phosphorous was non-significantly higher in conventional farming than bio-accelerated farming (Table 4). The application of different source of organic manures significantly enhances the nitrogen and phosphorus uptake as reported by Bhavya et al. (2018). The average pooled data revealed that the potassium uptake was maximum recorded under the conventional farming $\left(123.60 \mathrm{~kg} \mathrm{ha}^{-1}\right)$ than $(67.68$ $\mathrm{kg} \mathrm{ha}^{-1}$ ) in bio-accelerated farming (Table 3 ). This might be due the increased growth, nutrient influx and photosynthetic rate resulted in more absorption and translocation of these nutrients to the grain and stem. The ' $t$ '-test results showed that conventional farming uptake of potassium was highly significant than bio-accelerated farming (Table 4). Soil fertility was more or less uniform in both the set of cultivation practices at the beginning of the experiment. Therefore, application of nutrients in the easily available form from inorganic fertilizers recorded more uptake of NPK by the crop as compared to the crops under bio-accelerated farming practices. However, higher fertilizer use efficiency is always associated with low fertilizer rate, cultural practices meant for promoting integrated nutrient management will help to affect saving in the amount of fertilizer applied to the crops and therefore to improve fertilizer use efficiency (Karim and Ramasamy, 2000, Yadav, 2003).

\subsection{Quality parameters}

Quality parameters such as phenol and OD phenol also analyses at 30 days after sowing and at maturity of crop. Among the different compounds of phenol and OD phenol was also estimated. Phenol and OD phenol were recorded higher in bio-accelerated than the conventional farming at 30 DAS and at maturity stage. From the pooled data showed $0.24 \mathrm{mg} \mathrm{g}^{-1}$ and $0.21 \mathrm{mg} \mathrm{g}^{-1}$ of phenol were recorded at 30 DAS in bio-accelerated and conventional farming. At maturity, $7.80 \mathrm{mg} \mathrm{g}^{-1}$ and $7.14 \mathrm{mg} \mathrm{g}^{-1}$ of phenol were recorded in bioaccelerated and conventional farming system. The highest OD phenol was recorded under bio-accelerated farming $(0.05$ $\left.\mathrm{mg} \mathrm{g}^{-1}\right)$ compared to the conventional farming system (0.04 $\mathrm{mg} \mathrm{g}^{-1}$ ) at 30 DAS. At maturity $0.47 \mathrm{mg} \mathrm{g}^{-1}$ and $0.36 \mathrm{mg} \mathrm{g}^{-1}$ of OD phenol were recorded at maturity in bio-accelerated and conventional farming (Table 5). ' $\mathrm{t}$ '-test revealed that, phenol and OD phenol were found significantly higher in bio-accelerated farming than conventional farming on all

Table 5: Estimation of phenol and OD phenol in different cultivation practices $\left(\mathrm{mg} \mathrm{g}^{-1}\right)$

\begin{tabular}{lcccccc}
\hline \multirow{2}{*}{ Nutrients } & \multicolumn{3}{c}{$1^{\text {st }}$ year } & \multicolumn{2}{c}{$2^{\text {nd }}$ year } & \multicolumn{2}{c}{ Pooled } \\
\cline { 2 - 6 } & BF & CF & BF & CF & BF & CF \\
\hline Phenol (30 DAS) & 0.05 & 0.05 & 0.44 & 0.38 & 0.24 & 0.21 \\
Phenol (at maturity) & 7.26 & 6.82 & 8.34 & 7.46 & 7.80 & 7.14 \\
OD Phenol (30 DAS) & 0.05 & 0.03 & 0.04 & 0.04 & 0.05 & 0.04 \\
OD Phenol (at maturity) & 0.49 & 0.35 & 0.45 & 0.37 & 0.47 & 0.36 \\
BF: Bio-accelerated farming; CF: Conventional farming & & & & & \\
\hline
\end{tabular}

the growth stages except at 30 DAS where phenol showed non-significant difference (Table 6).

\subsection{Estimation of micro-organism (cfu)}

The application of organics i.e., jiwanmrita recorded significantly higher number of microbial population in the soil of bio-accelerated farming than the plots in conventional farming. Pooled analysis showed 62.50 microbes in bioaccelerated and 39.75 microbes in conventional farming before sowing which increased up to 97.25 microbes and decreased to 31.94 microbes in bio-accelerated and conventional farming respectively at the stage of maturity 
Table 6: ' $\mathrm{t}$ '-test analysis on phenol and OD phenol estimation in different cultivation practices

\begin{tabular}{lcccc}
\hline $\begin{array}{l}\text { Nutri- } \\
\text { ents }\end{array}$ & $\begin{array}{c}\text { Phenol } \\
\text { (30 DAS) }\end{array}$ & $\begin{array}{c}\text { Phenol } \\
\text { (at maturity) }\end{array}$ & $\begin{array}{c}\text { OD phenol } \\
\text { (30 DAS) }\end{array}$ & $\begin{array}{c}\text { OD phenol } \\
\text { (at maturity) }\end{array}$ \\
\hline t-value & -1.68 & -17.75 & -1.76 & -1.69 \\
Pr>t & 0.1042 & $<.0001$ & 0.0893 & 0.1005 \\
\hline
\end{tabular}

DAS: Days after sowing

(Table 7). This was due to the application of organic manures increased organic matter in soil ultimately enhancing microbial activity which reflected in the possible increase of nutrient status of soil (Reddy et al., 2007). From the' $t^{\prime}$-test value it

Table 7: Estimation of micro-organism in soil (cfu)

\begin{tabular}{lcccccc}
\hline \multirow{2}{*}{ Nutrients } & \multicolumn{2}{c}{$1^{\text {st }}$ year } & \multicolumn{2}{c}{$2^{\text {nd }}$ year } & \multicolumn{2}{c}{ Pooled } \\
\cline { 2 - 7 } & BF & CF & BF & CF & BF & CF \\
\hline $\begin{array}{l}\text { Microbes } \\
\text { (before } \\
\text { sowing) }\end{array}$ & 50.63 & 46.88 & 74.38 & 32.63 & 62.50 & 39.75 \\
$\begin{array}{l}\text { Microbes } \\
\text { (at matu- } \\
\text { rity) }\end{array}$ & 87.13 & 33.13 & 107.38 & 30.75 & 97.25 & 31.94 \\
\hline
\end{tabular}

BF: Bio-accelerated farming; CF: Conventional farming

was reveled that the microbial population was significantly higher in bio-accelerated farming over conventional farming system. The higher population of microbes helped in better decomposition of organics and mulches, which resulted in better release of nutrients and conservation of more moisture throughout the crop growing period resulted in higher yields as that of conventional treatments (Table 8).

Table 8: ' $\mathrm{t}$ '-test analysis for estimation of micro-organism in soil

\begin{tabular}{lcc}
\hline Observation & $\begin{array}{c}\text { Microbes } \\
\text { (before sowing) }\end{array}$ & $\begin{array}{c}\text { Microbes } \\
\text { (at maturity) }\end{array}$ \\
\hline t-value & 7.07 & 0.90 \\
Pr>t & $<.0001$ & 0.3749 \\
\hline
\end{tabular}

DAS: Days after sowing

3.6. Impact of different insect pest incidence in bio-accelerated and conventional farming system

In view of this, seasonal abundance of some important insectpests of green gram as well as the role of weather parameters on fluctuation of their populations was studied in the present investigation. Several number of insect-pests was found during the studies namely cutworm (Agrotis ipsilon Hufnagel), whitefly (Bemisia tabaci Gennadius), leaf folder (Lamprosema indica F.), leafminer (Liriomyza trifolii Burgess), bihar hairy caterpillar (Spilosoma oblique Walker), flea beetle (Phyllotreta sp.), pod borers (Maruca testulalis Geyer) jassid (Empoascca kerri Pruthi) etc. on green gram crop. Among the different insect-pests attacked on green gram cut worm, leaf folder, flea beetle and pod borer were found most predominant and persistently appeared on green gram. However, cutworm generally attacked on the initial stage (seedling stage) of crop growth up to 30-40 DAS (Table 9). However the pest appeared first after 12 days of sowing and damaging symptom persisted for one month. It was revealed that from the pooled data, maximum level of cut worm prevailed more in bio-accelerated farming $\left(1.20 \mathrm{~m}^{-1}\right)$ than conventional farming system $\left(0.60 \mathrm{~m}^{-1}\right)$ respectively on $16^{\text {th }} \mathrm{SW}$. Cutworm existed more in bio-accelerated farming than conventional farming. ' $\mathrm{t}$ '-test revealed that bio-accelerated farming were infested more by cutworm than conventional farming and significant variation were existed between them (Table 10). Leaf folder incidence was recorded from last week of April (30 DAS or $17^{\text {th }}$ $\mathrm{SW})$ in $1^{\text {st }}$ year and $3^{\text {rd }}$ week of April (15 DAS or $16^{\text {th }} \mathrm{SW}$ ) in the $2^{\text {nd }}$ year. The pest gradually increased to reach its maximum on $3^{\text {rd }}$ week of May $\left(20^{\text {th }} \mathrm{SW}\right)$ in both the treatments. From the pooled data it was revealed that the maximum leaf folder 1.97 per 10 plants and 1.27 per 10 plants in conventional and bio-accelerated farming and the significant difference between the treatments in almost all standard weeks were observed. ' $t$ '-test revealed that apart from $16^{\text {th }}$ and $21^{\text {st }}$ standard week (where non-significant relation existed), all the observations showed significant difference between bio-accelerated and conventional farming in regard to leaf folder population. From the pooled data the incidence of flea beetle existed throughout the crop growth period. The peak population was 3.67 per 10 plants in conventional farming and 1.67 per 10 plants in bio-accelerated farming. The data also suggested the significant variation existence $\left(15^{\text {th }} \mathrm{SW}\right.$ and $20^{\text {th }} \mathrm{SW}$ were non-significant) between bio-accelerated and conventional farming. ' $t$ '-test revealed that, apart from $15^{\text {th }}$ and $20^{\text {th }}$ standard week (where non-significant relation existed between the treatments) all the observations showed significant variation and conventional farming recorded significantly higher pest population as compared to bioaccelerated farming practices. The population of pod borer was initiated from last week of April ( $30 \mathrm{DAS}, 17^{\text {th }} \mathrm{SW}$ ) in $1^{\text {st }}$ year and $1^{\text {st }}$ week of May (30 DAS, $18^{\text {th }} \mathrm{SW}$ ) in $2^{\text {nd }}$ year at the period of flower initiation stage (Table 9). The incidence of pod borer attained its peak on $20^{\text {th }} \mathrm{SW}$ on pod development stage in both conventional farming and bio-accelerated farming. Pooled mean showed that the highest density of pest population was observed in conventional (13.97 per 10 plants) than bio-accelerated farming practices (9.50 per 10 plants). ' $t$ '-test suggested that, pod borer population was recorded significantly higher in conventional farming than bioaccelerated farming on all the observations made (Table 10). The pooled analysis suggested that the jassid population was more in conventional farming than bio-accelerated farming. The maximum population was recorded in conventional farming (3.27 plant ${ }^{-1}$ ) against bio-accelerated farming (1.60 plant $^{-1}$ ) in $19^{\text {th }} \mathrm{SW}$. The pest was present till $21 \mathrm{SW}$. Hence, apart from $17^{\text {th }} \mathrm{SW}$ all the observation showed significant 


\begin{tabular}{|c|c|c|c|c|c|c|c|c|c|c|c|c|c|c|c|c|c|c|}
\hline \multirow{3}{*}{$\begin{array}{l}\text { Std. } \\
\text { Wk. }\end{array}$} & \multicolumn{6}{|c|}{ Cutworm $\mathrm{M}^{-2}$} & \multicolumn{6}{|c|}{ 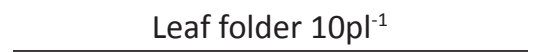 } & \multicolumn{6}{|c|}{ Flea beetle $10 \mathrm{pl}^{-1}$} \\
\hline & \multicolumn{2}{|c|}{$1^{\text {st }}$ year } & \multicolumn{2}{|c|}{$2^{\text {nd }}$ year } & \multicolumn{2}{|c|}{ Pooled } & \multicolumn{2}{|c|}{$1^{\text {st }}$ year } & \multicolumn{2}{|c|}{$2^{\text {nd }}$ year } & \multicolumn{2}{|c|}{ Pooled } & \multicolumn{2}{|c|}{$1^{\text {st }}$ year } & \multicolumn{2}{|c|}{$2^{\text {nd }}$ year } & \multicolumn{2}{|c|}{ Pooled } \\
\hline & $\mathrm{BF}$ & $\mathrm{CF}$ & $\mathrm{BF}$ & CF & $\mathrm{BF}$ & $\mathrm{CF}$ & $\mathrm{BF}$ & $\mathrm{CF}$ & $\mathrm{BF}$ & $\mathrm{CF}$ & BF & $\mathrm{CF}$ & BF & CF & BF & $\mathrm{CF}$ & $\mathrm{BF}$ & $\mathrm{CF}$ \\
\hline \multirow[t]{2}{*}{14} & 0.00 & 0.00 & 0.00 & 0.00 & 0.00 & 0.00 & 0.00 & 0.00 & 0.00 & 0.00 & 0.00 & 0.00 & 0.00 & 0.00 & 0.00 & 0.00 & 0.00 & 0.00 \\
\hline & 0.71 & 0.71 & 0.71 & 0.71 & 0.71 & 0.71 & 0.71 & 0.71 & 0.71 & 0.71 & 0.71 & 0.71 & 0.71 & 0.71 & 0.71 & 0.71 & 0.71 & 0.71 \\
\hline \multirow[t]{2}{*}{15} & 0.20 & 0.00 & 1.00 & 0.00 & 0.60 & 0.00 & 0.00 & 0.00 & 0.00 & 0.00 & 0.00 & 0.00 & 0.00 & 0.00 & 0.00 & 0.27 & 0.00 & 0.13 \\
\hline & 0.84 & 0.71 & 1.23 & 0.71 & 1.05 & 0.71 & 0.71 & 0.71 & 0.71 & 0.71 & 0.71 & 0.71 & 0.71 & 0.71 & 0.71 & 0.88 & 0.71 & 0.80 \\
\hline \multirow[t]{2}{*}{16} & 2.07 & 0.93 & 0.33 & 0.27 & 1.20 & 0.60 & 0.00 & 0.00 & 0.73 & 1.87 & 0.37 & 0.93 & 1.73 & 1.80 & 1.33 & 2.47 & 1.53 & 2.13 \\
\hline & 1.61 & 1.20 & 0.92 & 0.88 & 1.31 & 1.05 & 0.71 & 0.71 & 1.11 & 1.54 & 0.94 & 1.20 & 1.50 & 1.52 & 1.36 & 1.73 & 1.43 & 1.62 \\
\hline \multirow[t]{2}{*}{17} & 0.67 & 0.00 & 0.27 & 0.00 & 0.47 & 0.00 & 1.00 & 1.93 & 1.53 & 2.00 & 1.27 & 1.97 & 1.33 & 1.87 & 2.00 & 4.47 & 1.67 & 3.17 \\
\hline & 1.09 & 0.71 & 0.88 & 0.71 & 0.99 & 0.71 & 1.23 & 1.56 & 1.43 & 1.58 & 1.33 & 1.57 & 1.36 & 1.54 & 1.58 & 2.23 & 1.48 & 1.92 \\
\hline \multirow[t]{2}{*}{18} & 0.47 & 0.00 & 0.07 & 0.00 & 0.27 & 0.00 & 0.00 & 0.73 & 1.73 & 3.33 & 0.87 & 2.03 & 1.27 & 1.80 & 2.00 & 2.87 & 1.63 & 2.33 \\
\hline & 0.99 & 0.71 & 0.76 & 0.71 & 0.88 & 0.71 & 0.71 & 1.11 & 1.50 & 1.96 & 1.17 & 1.59 & 1.33 & 1.52 & 1.58 & 1.84 & 1.46 & 1.69 \\
\hline \multirow[t]{2}{*}{19} & 0.00 & 0.00 & 0.00 & 0.00 & 0.00 & 0.00 & 0.73 & 1.27 & 0.53 & 0.93 & 0.63 & 1.10 & 1.47 & 1.93 & 1.07 & 3.13 & 1.27 & 2.53 \\
\hline & 0.71 & 0.71 & 0.71 & 0.71 & 0.71 & 0.71 & 1.11 & 1.33 & 1.02 & 1.20 & 1.07 & 1.27 & 1.41 & 1.56 & 1.26 & 1.91 & 1.33 & 1.74 \\
\hline \multirow[t]{2}{*}{20} & 0.00 & 0.00 & 0.00 & 0.00 & 0.00 & 0.00 & 1.33 & 2.07 & 0.80 & 1.40 & 1.07 & 1.73 & 0.33 & 0.60 & 3.87 & 6.54 & 2.10 & 3.57 \\
\hline & 0.71 & 0.71 & 0.71 & 0.71 & 0.71 & 0.71 & 1.36 & 1.61 & 1.14 & 1.38 & 1.26 & 1.50 & 0.92 & 1.05 & 2.09 & 2.66 & 1.62 & 2.02 \\
\hline \multirow[t]{2}{*}{21} & 0.00 & 0.00 & 0.00 & 0.00 & 0.00 & 0.00 & 0.20 & 0.60 & 0.47 & 0.67 & 0.33 & 0.63 & 0.27 & 0.67 & 0.67 & 1.73 & 0.47 & 1.20 \\
\hline & 0.71 & 0.71 & 0.71 & 0.71 & 0.71 & 0.71 & 0.84 & 1.05 & 0.99 & 1.09 & 0.92 & 1.07 & 0.88 & 1.09 & 1.09 & 1.50 & 0.99 & 1.31 \\
\hline \multirow[t]{2}{*}{22} & 0.00 & 0.00 & 0.00 & 0.00 & 0.00 & 0.00 & 0.00 & 0.27 & 0.00 & 0.67 & 0.00 & 0.47 & 0.27 & 1.27 & 0.67 & 2.07 & 0.47 & 1.67 \\
\hline & 0.71 & 0.71 & 0.71 & 0.71 & 0.71 & 0.71 & 0.71 & 0.88 & 0.71 & 1.09 & 0.71 & 0.99 & 0.88 & 1.33 & 1.09 & 1.61 & 0.99 & 1.48 \\
\hline \multirow[t]{2}{*}{ Mean } & & & & & 0.28 & 0.07 & & & & & 0.50 & 0.98 & & & & & 1.02 & 1.86 \\
\hline & & & & & 0.88 & 0.75 & & & & & 1.00 & 1.22 & & & & & 1.23 & 1.54 \\
\hline
\end{tabular}

Table 9: Continue...

\begin{tabular}{|c|c|c|c|c|c|c|c|c|c|c|c|c|}
\hline \multirow[t]{3}{*}{ Std. Wk. } & \multicolumn{6}{|c|}{ Pod borer $10 \mathrm{pl}^{-1}$} & \multicolumn{6}{|c|}{ Jassid $\mathrm{pl}^{-1}$} \\
\hline & \multicolumn{2}{|c|}{$1^{\text {st }}$ year } & \multicolumn{2}{|c|}{$2^{\text {nd }}$ year } & \multicolumn{2}{|c|}{ Pooled } & \multicolumn{2}{|c|}{$1^{\text {st }}$ year } & \multicolumn{2}{|c|}{$2^{\text {nd }}$ year } & \multicolumn{2}{|c|}{ Pooled } \\
\hline & $\mathrm{BF}$ & $\mathrm{CF}$ & $\mathrm{BF}$ & $\mathrm{CF}$ & $\mathrm{BF}$ & $\mathrm{CF}$ & $\mathrm{BF}$ & $\mathrm{CF}$ & $\mathrm{BF}$ & $\mathrm{CF}$ & $\mathrm{BF}$ & $\mathrm{CF}$ \\
\hline \multirow[t]{2}{*}{14} & 0.00 & 0.00 & 0.00 & 0.00 & 0.00 & 0.00 & 0.00 & 0.00 & 0.00 & 0.00 & 0.00 & 0.00 \\
\hline & 0.71 & 0.71 & 0.71 & 0.71 & 0.71 & 0.71 & 0.71 & 0.71 & 0.71 & 0.71 & 0.71 & 0.71 \\
\hline \multirow[t]{2}{*}{15} & 0.00 & 0.00 & 0.00 & 0.00 & 0.00 & 0.00 & 0.00 & 0.00 & 0.00 & 0.00 & 0.00 & 0.00 \\
\hline & 0.71 & 0.71 & 0.71 & 0.71 & 0.71 & 0.71 & 0.71 & 0.71 & 0.71 & 0.71 & 0.71 & 0.71 \\
\hline \multirow[t]{2}{*}{16} & 0.00 & 0.00 & 0.00 & 0.00 & 0.00 & 0.00 & 0.00 & 0.00 & 0.00 & 0.00 & 0.00 & 0.00 \\
\hline & 0.71 & 0.71 & 0.71 & 0.71 & 0.71 & 0.71 & 0.71 & 0.71 & 0.71 & 0.71 & 0.71 & 0.71 \\
\hline \multirow[t]{2}{*}{17} & 0.53 & 2.13 & 0.00 & 0.00 & 0.27 & 1.07 & 0.00 & 0.00 & 0.00 & 0.07 & 0.00 & 0.03 \\
\hline & 1.02 & 1.62 & 0.71 & 0.71 & 0.88 & 1.26 & 0.71 & 0.71 & 0.71 & 0.76 & 0.71 & 0.73 \\
\hline \multirow[t]{2}{*}{18} & 1.67 & 4.93 & 1.53 & 3.67 & 1.60 & 4.30 & 0.60 & 1.53 & 0.47 & 2.07 & 0.53 & 1.80 \\
\hline & 1.48 & 2.33 & 1.43 & 2.04 & 1.45 & 2.19 & 1.05 & 1.43 & 0.99 & 1.61 & 1.02 & 1.52 \\
\hline \multirow[t]{2}{*}{19} & 7.27 & 12.27 & 2.13 & 4.40 & 4.70 & 8.33 & 2.07 & 3.73 & 1.13 & 2.80 & 1.60 & 3.27 \\
\hline & 2.79 & 3.57 & 1.62 & 2.22 & 2.28 & 2.97 & 1.61 & 2.06 & 1.28 & 1.82 & 1.45 & 1.94 \\
\hline \multirow[t]{2}{*}{20} & 8.60 & 11.93 & 10.40 & 16.00 & 9.50 & 13.97 & 0.47 & 2.20 & 0.07 & 2.00 & 0.27 & 2.10 \\
\hline & 3.02 & 3.53 & 3.30 & 4.06 & 3.16 & 3.81 & 0.99 & 1.65 & 0.76 & 1.58 & 0.88 & 1.62 \\
\hline
\end{tabular}




\begin{tabular}{|c|c|c|c|c|c|c|c|c|c|c|c|c|}
\hline \multirow[t]{3}{*}{ Std. Wk. } & \multicolumn{6}{|c|}{ Pod borer $10 \mathrm{pl}^{-1}$} & \multicolumn{6}{|c|}{ Jassid $\mathrm{pl}^{-1}$} \\
\hline & \multicolumn{2}{|c|}{$1^{\text {st }}$ year } & \multicolumn{2}{|c|}{$2^{\text {nd }}$ year } & \multicolumn{2}{|c|}{ Pooled } & \multicolumn{2}{|c|}{$1^{\text {st }}$ year } & \multicolumn{2}{|c|}{$2^{\text {nd }}$ year } & \multicolumn{2}{|c|}{ Pooled } \\
\hline & $\mathrm{BF}$ & $\mathrm{CF}$ & $\mathrm{BF}$ & $\mathrm{CF}$ & $\mathrm{BF}$ & $\mathrm{CF}$ & $\mathrm{BF}$ & $\mathrm{CF}$ & $\mathrm{BF}$ & $\mathrm{CF}$ & $\mathrm{BF}$ & $\mathrm{CF}$ \\
\hline \multirow[t]{2}{*}{21} & 5.33 & 7.73 & 4.80 & 7.00 & 5.07 & 7.37 & 0.00 & 0.00 & 0.00 & 0.13 & 0.00 & 0.07 \\
\hline & 2.42 & 2.87 & 2.30 & 2.74 & 2.36 & 2.81 & 0.71 & 0.71 & 0.71 & 0.80 & 0.71 & 0.76 \\
\hline \multirow[t]{2}{*}{22} & 0.00 & 0.00 & 0.00 & 0.00 & 0.00 & 0.00 & 0.00 & 0.00 & 0.00 & 0.00 & 0.00 & 0.00 \\
\hline & 0.71 & 0.71 & 0.71 & 0.71 & 0.71 & 0.71 & 0.71 & 0.71 & 0.71 & 0.71 & 0.71 & 0.71 \\
\hline \multirow[t]{2}{*}{ Mean } & & & & & 2.35 & 3.89 & & & & & 0.27 & 0.81 \\
\hline & & & & & 1.69 & 2.10 & & & & & 0.88 & 1.14 \\
\hline
\end{tabular}

BF: Bio-accelerated farming; CF: Conventional farming; DAS: Days after sowing; Figure in parentheses are square root transformed values

\begin{tabular}{lccccccccc}
\hline \multicolumn{7}{l}{ Table 10: 't'-test analysis on effect of cultivation practices of green gram on the incidence of different pest } \\
\hline PEST & Std.Wk. & 15 & 16 & 17 & 18 & 19 & 20 & 21 & 22 \\
\hline Cutworm & $\mathrm{t}$-value & 4.65 & 2.01 & 3.39 & 3.05 & - & - & - & - \\
& Pr>t & $<.0001$ & 0.0536 & 0.0004 & 0.0048 & - & - & - & - \\
\multirow{4}{*}{ Leaf folder } & $\mathrm{t}$-value & - & -1.61 & -2.79 & -2.59 & -2.85 & -3.35 & -1.74 & -4.17 \\
& Pr>t & - & 0.1180 & 0.009 & 0.0145 & 0.0079 & 0.0022 & 0.0925 & 0.0002 \\
Flea beetle & $\mathrm{t}$-value & -1.97 & -2.41 & -3.46 & -2.31 & -5.35 & -1.31 & -3.35 & -5.45 \\
& Pr>t & 0.058 & 0.0221 & 0.0016 & 0.0282 & $<.0001$ & 0.2013 & 0.0022 & $<.0001$ \\
\multirow{2}{*}{ Pod borer } & $\mathrm{t}$-value & - & - & -2.40 & -8.52 & -2.69 & -4.51 & -4.92 & - \\
& Pr>t & - & - & 0.0230 & $<.0001$ & 0.0115 & $<.0001$ & $<.0001$ & - \\
Jassid & $\mathrm{t}$-value & - & - & -1.56 & -5.49 & -5.75 & -10.52 & -2.15 & - \\
& Pr>t & - & - & 0.1295 & $<.0001$ & $<.0001$ & $<.0001$ & 0.0401 & - \\
\hline
\end{tabular}

Std. Wk.: standard week

variation between the treatments (Table 9). This might be due to the high humidity, moderate to high temperature and low rainfalls are found to be conducive for growth and multiplication of jassid. ' $\mathrm{t}$ '-test revealed that conventional farming were attacked more by the pest than bio-accelerated farming and had significant variation between them on all the observations from $18^{\text {th }}$ standard week to $21^{\text {st }}$ standard week except $17^{\text {th }}$ standard where non-significant relation existed between the treatments (Table 10). However this might be due to the conventional farming system (high cropping intensity, HYVs, increased use of fertilizers) has boosted the crop growth but at the same time it invited a level of pest to the crops. A general trend to use high dose of $\mathrm{N}$ fertilizers than $\mathrm{P}, \mathrm{K}$ accordingly by the farmers increased the succulency of greengram plants resulting the attack of large number of insect-pests. On the contrary, bio-accelerated farming maintained the optimum growth of the plant by improving the soil physico-chemical properties and enhances microbial activity through use of organic mulching, cowdung and cow urine etc (jiwamrita) and these process provided resistance to the respective crop against pest infestation. The results on the incidence of rice insect-pests are in conformity with the findings of many workers (Fang and Huanchao, 2007;
Mulumba and Rattan 2008; Goswami and Das, 2009).

\subsection{Impact of abiotic factors on the incidence of different} insect pest on green gram

The highest cutworm population was found in the green gram plant on $15^{\text {th }}, 16^{\text {th }}, 17^{\text {th }}$ and $18^{\text {th }}$ standard week when the average temperature ranges from $28.37^{\circ} \mathrm{C}$ to $28.95^{\circ} \mathrm{C}$; the temperature gradient from 8.57 to 11.57 ; average rh (76.50\% to $77.96 \%)$ and rh gradient $(5.00 \%$ to $13.57 \%)$. The rainfall was moderate when the cutworm population reached the peak as $4.49 \mathrm{~mm}$ of rainfall was recorded during $16^{\text {th }}$ standard week. Hence, it can be said that, high humidity, moderate temperature and low rainfall are found to be conducive for growth and multiplication of cutworm. The population of leaf folder was found during $16^{\text {th }}, 17^{\text {th }}, 18^{\text {th }}, 19^{\text {th }}$, $20^{\text {th }}, 21^{\text {st }}$ and $22^{\text {nd }}$ standards weeks with the average range temperature of $28.37{ }^{\circ} \mathrm{C}-30.52{ }^{\circ} \mathrm{C}$; temperature gradient range of $7.71{ }^{\circ} \mathrm{C}-10.15^{\circ} \mathrm{C}$; average relative humidity of $76.50 \%$ $-81.60 \%$ and relative humidity gradient of $3.75-11.24$. $3.75 \mathrm{~mm}$ of rainfall was recorded during the peak infestation period. Hence, it can be concluded that, moderate to high temperature, high humidity and low rainfall are conducive for the growth and multiplication of leaf folder. It was revealed 
from the Table 11 that the flea beetle population was found in the green gram from $15^{\text {th }}$ to $22^{\text {nd }}$ standard week when the average temperature ranges from $28.40{ }^{\circ} \mathrm{C}$ to $30.52{ }^{\circ} \mathrm{C}$; the temperature gradient from 7.71 to 11.57 ; average $\mathrm{rh}(76.50 \%$ to $81.60 \%)$ and rh gradient $(5.00 \%$ to $13.57 \%)$. The rainfall was moderate when the flea beetle population reached the peak as $11.24 \mathrm{~mm}$ of rainfall was recorded during $20^{\text {th }}$ standard week. Therefore, it can be said that, high humidity, moderate to high temperature and moderate rainfall are found to be conducive for growth and multiplication of flea beetle population. The pod borer population was found on $17^{\text {th }}, 18$ th $, 19^{\text {th }}, 20^{\text {th }}, 21^{\text {th }}$ and $22^{\text {nd }}$ standard week in greengram when the average temperature ranges from $28.40{ }^{\circ} \mathrm{C}$ to 30.52 ${ }^{\circ} \mathrm{C}$; the temperature gradient from 7.71 to 9.57 ; average $\mathrm{rh}$ (76.50\% to $81.60 \%$ ) and rh gradient $(5.00 \%$ to $12.14 \%)$. The rainfall was moderate when the pod borer population reached the peak as $11.24 \mathrm{~mm}$ of rainfall was recorded during $20^{\text {th }}$ standard week. Therefore, it can be said that, high humidity, moderate to high temperature and moderate rainfall are found to be conducive for growth and multiplication of pod borer population. It was recorded that the jassid population was found in greengram plant on $17^{\text {th }}, 18^{\text {th }}, 19^{\text {th }}, 20^{\text {th }}$ and $21^{\text {st }}$ standard week when the average temperature ranges from $28.40{ }^{\circ} \mathrm{C}$ to $30.19^{\circ} \mathrm{C}$; the temperature gradient from 7.71 to 9.57; average rh (76.50\% to $79.94 \%)$ and rh gradient $(5.00 \%$ to $12.14 \%$ ). The rainfall was the minimum of $3.75 \mathrm{~mm}$ during $19^{\text {th }} \mathrm{SW}$ when the jassid population reached the peak.

The different insect pests such as cutworm, leaf roller, flea beetle, pod borer and jassid were found infesting greengram. The multiple regression equation (Table 11) showed that weather parameters, in most of the cases had no significant impact on the population of these pests. Only temperature average and temperature gradient revealed significant negative impact against leaf roller and flea beetle in both bio-accelerated and conventional farming system. Impact of weather parameters in together was found $86.7 \%$ and $75.5 \%$ against leaf roller in bio-accelerated and conventional farming respectively whereas $89.9 \%$ and $88.6 \%$ contribution of weather factors in total were noticed against flea beetle in both the farming system (Table 11). In other insect pests, weather parameters had no significant impact on their population development.

\begin{tabular}{|c|c|c|c|c|}
\hline SI. No. & Pest & Treatments & Equation & $\mathrm{R}^{2}$ \\
\hline \multirow[t]{2}{*}{1} & \multirow[t]{2}{*}{ Cut worm } & Bio-accelerated farming & $Y=4.198-0.312_{x 1}+0.075_{x 2}+0.058_{x 3}-0.005_{x 4}+0.004_{x 5}$ & 0.470 \\
\hline & & Conventional farming & $Y=0.388-0.103_{x 1}+0.067_{x 2}+0.028_{x 3}-0.022_{x 4}+0.010_{x 5}$ & 0.347 \\
\hline \multirow[t]{2}{*}{2} & \multirow[t]{2}{*}{ Leaf roller } & Bio-accelerated farming & $Y=14.428-0.500_{x 1}^{* *}-0.389_{x 2}^{* *}+0.056_{x 3}+0.023_{x 4}-0.041_{x 5}$ & 0.867 \\
\hline & & Conventional farming & $Y=16.514-0.765_{x 1}^{*}-0.614_{x 2}^{*}+0.162_{x 3}+0.042_{x 4}-0.085_{x 5}$ & 0.755 \\
\hline \multirow[t]{2}{*}{3} & \multirow[t]{2}{*}{ Flea beetle } & Bio-accelerated farming & $Y=13.680-0.907_{x 1}{ }^{* *}-0.505_{x 2}{ }^{*}+0.243_{x 3}{ }^{*}-0.009_{x 4}-0.068_{x 5}$ & 0.899 \\
\hline & & Conventional farming & $Y=11.520-1.229_{x 1}^{*}-0.848_{x 2}^{*}+0.450_{x 3}^{*}-0.034_{x 4}-0.135_{x 5}$ & 0.886 \\
\hline \multirow[t]{2}{*}{4} & \multirow[t]{2}{*}{ Pod borer } & Bio-accelerated farming & $Y=12.132-1.141_{x 1}-1.651_{x 2}+0.534_{x 3}-0.226_{x 4}-0.206_{x 5}$ & 0.629 \\
\hline & & Conventional farming & $Y=23.955-1.808_{x 1}-2.902_{x 2}+0.817_{x 3}-0.247_{x 4}-0.405_{x 5}$ & 0.671 \\
\hline \multirow[t]{2}{*}{5} & \multirow[t]{2}{*}{ Jassid } & Bio-accelerated farming & $Y=-2.386+0.024_{x 1}-0.266_{x 2}+0.063_{x 3}-0.004_{x 4}-0.067_{x 5}$ & 0.470 \\
\hline & & Conventional farming & $Y=-0.688-0.367_{x 1}-0.757_{x 2}+0.259_{x 3}+0.005_{x 4}-0.156_{x 5}$ & 0.572 \\
\hline
\end{tabular}

Where, $\mathrm{x}_{1}$ : Average temperature; $\mathrm{x}_{2}$ : Temperature gradient; $\mathrm{x}_{3}$ : Average relative humidity; $\mathrm{x}_{4}$ : relative humidity gradient; $\mathrm{x}_{5}$ : Rainfall

\section{Conclusion}

The adoption of bio-accelerated against conventional farming system produces the quality crop restoring the quality of soil health and better grain quality, apart from facilitating the dynamics of organic matter decomposition and plant nutrient availability. The better economic returns in bio-accelerated farming system also proved its superiority. Bio-accelerated farming system enhanced the plant growth; yield response as well as qualitative development of soil especially micro floral attributes indicated the relevance of comprehensive organic approach towards reversal of the imperiled sustainability in agriculture.

\section{References}

Anonymous, 2016. Pulses in India: retrospect and prospects.
National food Security Mission, 84.

Azadi, E., Rafiee, M., Hadis, N., 2013. The effect of different nitrogen levels on seed yield and morphological characteristic of mungbean in the climate condition of Khorramabad. Annals of Biological Research 4(2), 51-55.

Baishya, K., 2015. Impact of agrochemicals application on Soil quality degradation- A review. International Journal of Science Technology and Management 4(1), 220-228.

Bhavya, G., Chandra Shaker, K., Jayasree, G., Reddy, M.M., 2018. Nutrient uptake and yield of green gram (Vigna radiata L.) as influenced by phosphorus fertilization, organic manures and biofertilizers. International Journal of Chemical Studies 6(3), 32-35.

Dekhane, S.S., Khafi, H.R., Raj, A.D., Parmar, R.M., 2011. Effect of bio fertilizer and fertility levels on yield, 
protein content and nutrient uptake of cowpea (Vigna unguiculata L.). Legume Research 34(1), 51-54.

Fang, S., Xie, B., Zhang, H., 2007. Nitrogen dynamics and mineralization in degraded agricultural soil mulched with fresh grass. Plant and soil 300(1-2), 269-280.

Ginting, D., Kessavalou, A., Eghball, B., Doran, J.W., 2003. Greenhouse gas emissions and soil indicators four years after manure compost application. Journal of Environment Quality 32, 23-32.

Giri, N., Joshi, N.C., 2010. Growth and yield response of chick pea (Cicer arietinum) to seed inoculation with Rhizobium sp. Nature \& Science 8(9), 232-236.

Goswami, S.B., Das, S.K., 2009. Effect of bio-mulches on soil nutrient availability and microbial population in summer rice. Oryza 46(2), 103-107.

Karim, A.A., Ramasamy, C., 2000. Expanding frontiers of agriculture: contemporary issues. Kalyani Publishers, Ludhiana, India.

Kumar, R., 2014b. Assessment of technology gap and productivity gain through Crop technology demonstration in chickpea. Indian Journal of Agriculture Research 48, 162-164.

Kumar, A., Reena, N.B., Kumar, J., Jamwal, B.S., 2010. Response of large seeded lentil to seed rate, phosphorus and FYM application in sub-tropical kandi-belt of Jammu and Kashmir. Journal of Food Legumes 23(1), 44-46.

Kumar, S., Kumar, R., 2006. Effect of farm yard manure, phosphorus levels and biofertiliser on productivity of lentil. Crop Research 31(3), 370-372.

Mulumba, L.N., Lal, R., 2008. Mulching effects on selected soil physical properties. Soil and tillage research 98(1), 106-111.

Palekar, S., 2001. The Philosophy of Spiritual Farming -Vol.1. Amrawati, Maharashtra, India.

Patel, R.D. 2012. Response of different cultivar of green gram (Vigna radiata L.) to integrated nutrient management under south Gujarat condition. M.Sc. (Agri.) Thesis submitted to Navsari Agricultural University, Navsari.

Paul, D.C., Subba Rao, G., Deb, D.C., 1992. Impact of dietary moisture on nutritional indices and growth of Bombyx mori and Concomitant larval duration. Journal of Insect Physiology 38, 229.

Rajkhowa, D.J., Saikia, M., Rajkhowa, K.M., 2003. Effect of vermicompost and levels of fertilizer on greengram. Legume Research 26(1), 63-65.

Ravi, N., Basavarajappa, R., Chandrashekar, C.P., Harlapur, S.I., Hosamani, M.H., Manjunatha, M.V., 2012. Effect of integrated nutrient management on growth and yield of quality protein maize. Karnataka Journal Agricultural Science 25(3), 395-396.

Reddy, S., Rukmangada, V.C. Reddy, V.R., Ramakrishna, P., Pampa, S., 2007. Effect of sewage sludge, urban compost and FYM on juice quality and soil nutrient status of sweet sorghum. Journal Soils \& Crops 17(1), 30-34.

Saravanan, P., Singh, S.K., Kumar, I., 2013. Effect of organic manures and chemical fertilizers on the yield and macronutrient concentrations of green gram. International Journal of Pharmaceutical Science Invention ISSN (Online): 2319-6718, ISSN (Print): 2319-670X.

Sharma, R., Verma, M.L., 2011. Effect of Rhizobium, farmyard manure and chemical fertilizers on sustainable production and profitability of rajmash (Phaseolus vulgaris L.) and soil fertility in dry temperate region of North- western Himalayas. Legume Research 34(4), 251-258.

Singh, D., Singh, R.P., 2014. Effect of integrated nutrient management on growth, physiological parameters and productivity of lentil (Lens culinaris Medik.). International Journal of Agriculture Sciences 10(1), 175-178.

Sinha, J., Biswas, C.K., Ghosh, A., Saha, A., 2010. Efficacy of vermicompost against fertilizers on Cicer and Pisum on population diversity of $\mathrm{N}_{2}$ fixing bacteria. Journal of Environment Biology 31(3), 287-292.

Singh, G., Hari, R., Sekhon, H.S., Aggarwal, N., Khanna, V., 2011. Effect of nutrient management on nodulation, growth and yield of lentil (Lens culinaris Medik.) genotypes. American Eurasian Journal of Agronomy 4(3), 46-49.

Singh, A.B., Saha, J.K., Gosh, P.K., 2008. Effect of nutrient management practices on soybean (Glycine max)chickpea (Cicer arietinum) cropping systems for improving seed yield, quality and soil biological health under rainfed condition. Indian Journal of Agriculture Science 78(6), 485-489.

Singh, G., Sekhon, H.S., 2008. Effect of various inputs on the growth and yield of summer green gram (Vigna radiata). Indian Journal of Agricultural Sciences 78(1), 87-89.

Sutaria, G.S., Kabari, K.N., Vora, V.D., Hirpara, D.S., Padmani, D.R., 2010. Response of legume crops to enriched compost and vermicompost on Ustochrept under rainfed Agriculture. Legume Research 33(2), 128-130.

Tamang, D., Nath, R., Sengupta, K., 2015. Effect of herbicide application on weed management in greengram. Advances in Crop Science and Technology 3(2), 1-4.

Tanwar, S.P.S., Rokadia, P., Singh, A.K., 2010. Productivi y, nutrient balance and economics of kabul i chickpea (Cicer kabulium) as influenced by integrated nutrient management. Indian Journal of Agronomy 55(1), 51-55.

Tripura, P., Verma, R., Kumar, S., 2016. Effect of potassium humate and bio-inoculants on cowpea (Vigna unguiculata L. walp) influence of soil fertility, enzymatic activity and microbial population in soil. International Journal of Agriculture Science 8(53), 2638-2641.

Waksman, S.A., Fred, E.B., 1922. A tentative outline of the plate method for determining the number of microorganisms in the soil. Soil Science 14, 27-28.

Yadav, R.L., 2003. Assessing on farm efficiency and economics of fertilizer NP and K in rice wheat systems of India. Field Crops Research 18, 39-51. 